\title{
Financial Inclusion of Marginalised Communities: A Study on Fisher Households in Kerala
}

\author{
L. F. Sunitha \\ Research Scholar, Department of Economics, \\ University College, Thiruvananthapuram, Kerala, India \\ E-Mail: sunitha.odal.320@gmail.com
}

\begin{abstract}
Kerala, southern fringe of India has different story of development from the rest of Indian states. The implementation of different policies by the government has been resulted in the betterment of different marginalized communities, especially in the case of women empowerment. For women empowerment, state government has initiated many programs with the support of other local bodies including government and non-government organizations like Kudumbashree program, Gender park etc. It has created many opportunities for women to come forward to mainstream of the society and engaging in many public activities. This paper is an attempt to look at state sponsored program for fisher women empowerment called 'Society for Assistance to Fisherwomen' (SAF), for uplift of fisherwomen, with the support of both secondary material and ground reality. This paper also discusses about the need for an alternative model for the development of the marginalized fisher households sector.
\end{abstract}

Keywords: Financial Inclusion, SAF, CAD, SIFFS

\section{INTRODUCTION}

Fisheries are a promising sunrise sector in the national and State economies. The importance of fisheries sector in Kerala and the advantageous position in Kerala enjoys a maritime state is well known because this sector provides income and employment to more than one million people, either directly or indirectly. Apart from its contribution to GDP and employment, it stimulates growth in a number of subsidiary industries. It is a source of low-cost and nutritious food besides being a source of foreign exchange. India is the second largest fish producing nation in the world. India is also a major producer of fish through aquaculture and ranks second in the world after China. The total fish production during 2015-16 (provisional) is at 107.9 lakh tonnes with a contribution of 71.65 lakh tonnes from inland sector and 36.3 lakh tonnes from marine sector. Inland fish production constitutes 66 per cent of the total fish production of the country and annual growth rate of production has also been high. Though marine fish production has increased during the recent years, the growth rate is very low. Marine fisheries in India are supposed to be passing through a crisis due to over capacity and open access nature. The sector engaged over 14.50 million people at the primary level and many more along the value chain. Export earnings from the sector were 37,870.90 crore in 2016-17. The sector contributed about 0.9 per cent to the National Gross Value Added (GVA) and 5.43 per cent to the agricultural GVP (2015-16). Analysis of recent trend in exports of marine products suggests that though there was a fall in the quantity and value in 2015-16, it has increased in 2016-17.

It satisfies the protein requirements of a considerable chunk of the underprivileged population and it provides considerable revenue especially in foreign exchange, to the exchequer of state. The total fish production in Kerala during 2016-17 was 6.76 lakh tonnes, of which marine fish landings accounted for 4.88 lakh tonnes and inland fish production was 1.88 lakh tonnes. Year-wise details of fish production in Kerala are provided in Fig.1.

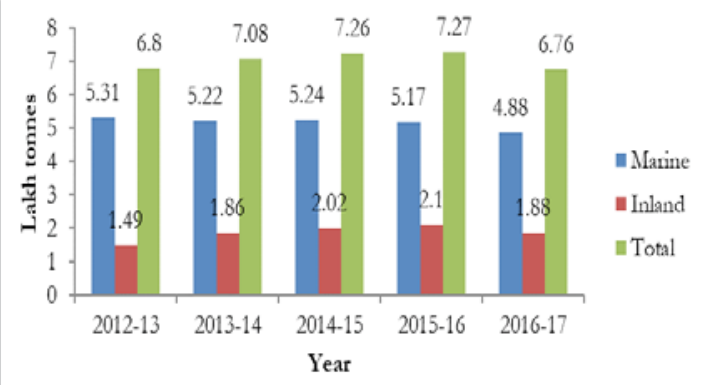

Source: Fisheries Department, Government of Kerala Fig. 1 Fish Production in Kerala (2012-13 to 2016-17)

Compared to 2015-16, marine, inland and total fish production fell in the State in 2016-17. The marine fishery resources of the State is said to have almost attained the optimum level of production. Marine fish landing in Kerala has been declining continuously since 2011-12, with the exception of a marginal increase in 2014-15. High value species among the fish catch is less. However, significant among them are Seer fish, Prawn, Ribbon fish and Mackerel. The quality of these high value species in the total catch ultimately decides the income of the fish workers.

At national-level, 66 per cent of the total fish production is contributed by the inland sector, however at the State level, the share of inland sector is only 28 per cent which is relatively less than the marine sector. The difference in the composition of total production in India and Kerala are brought out in the following fig.2. 
Inland fish production had showed signs of improvement from 1999-2000 and it had been increasing till 2015-16. Kerala has not utilized its potential in inland fishing. Kerala has over 7 per cent of the water bodies in the country, but its share in inland fishing is lower than that of many other States.

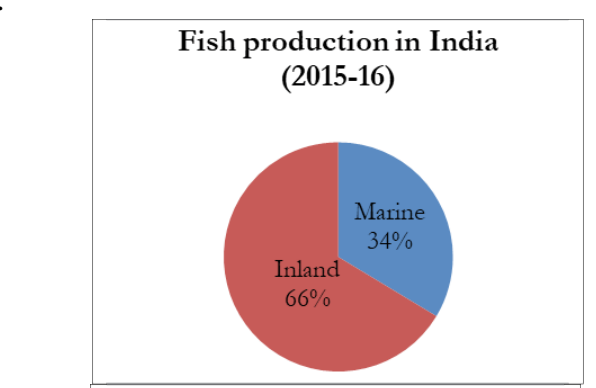

Fish production in kerala (2016-17)

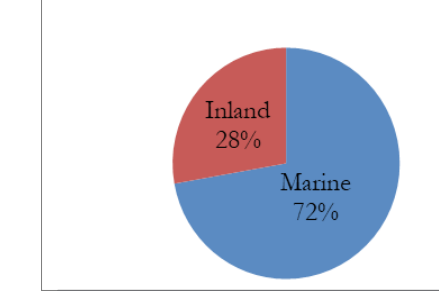

Source: Fisheries Department, GOK, DHFD, GOI

Fig. 2 Fish Production in India and Kerala - Relative Share of Marine and Inland

An analysis of the figures of district wise fish production in Kerala shows that the district of Kollam is the leading producer of marine fish followed by Ernakulam and Thiruvananthapuram. These 3 districts together contribute around 74 per cent of the total marine fish production in the State. Ernakulam, Alappuzha, and Thrissur are the leading districts in the case of inland fish production occupying the first, second and third positions respectively. If we look at total fish production, the leading producer is the district of Kollam followed by Ernakulam and Thiruvananthapuram respectively.

\section{A. Status of Fisher Households in Kerala}

Fisher households gain attention across the globe due to the peculiarity of the occupation, which involves high risk, irregular income and seasonal livelihood. Fisher households are backward in socio-economic status. It has been reported that 64 per cent of the fishermen households in Kerala were indebted and more than half of their liability was for buying fishing inputs (SIFFs, 2001; State Planning Board, Kerala, 2009). And that 21.1 per cent fisher population could not afford to meet basic needs as against the State's incidence of poverty figure was 9.4 per cent $(R, 2010)$. However, the contribution of this community to the economy is highly commendable as they provide employment to many and fetch foreign exchange, and guard the boundaries of the nation (ARD \& World Bank, 2010; (Dhanya, 2013). Fisher households are characterized by low per capita income, high dependency ratio, indebtedness, exploited by middlemen in the market, and less financial capability. Lack of alternative occupation and the low financial capability in planning, budgeting, saving and spending of the irregular and seasonal income make the fishery sector a high risk prone sector. A number of schemes by various international and national forums have been implemented to reduce the misery and guard the dignity of fishermen and to scale up the overall welfare of the fisher community around the world. The increased demand for sea food has prompted the fishermen across the globe resort to fishing intensification through extension of fishing ground; increase the overall length of the vessel, enhancing the HPs of OBMs. Adoption of irresponsible fishing methods like reducing the mesh size of the gears, competition between Mechanised vessels, trawlers and use of ring seiners have become the trend of the time to catch more and to earn more (Department of Fisheries, Kerala, 2012). Consequently, cutting the branch of the tree, where one is seated. This growing chase for sea food ultimately affect 171 the livelihood of traditional fisher folk who solely depend on this common resource (Namboothri, Muralidharan, \& Sridhar, 2012).

The traditional fishermen, who fight with the rough sea, have also to fight with the commercial sharks who eat up the profit of the poor fishermen that they earn for their livelihood. Here, the situation of the fishermen could be compared to the character of Ernest Hemingway's Santiago in his famous novel 'The Old Man and the Sea' who comes to the shore with the skeleton of the fish after the hard labour (Hemingway, 2007). Most of the fishing days the fishermen come to the shore with the debt burden ranging between 7000/- to 30000/-. A wake up call for deep-sea fishing could be heard to combat the present menace of declining fish production and endangering of the ecosystem, which means huge investment and intense training to fishermen in this sector. This responsibility cannot be shouldered by the fisher households alone, but a joint effort of the government agencies and formal financial institutions could easily address the need of the hour.

\section{B. Social Security and Livelihood Support to Fish Worker Community}

Government of Kerala has placed emphasis on various schemes implemented to ensure social security and livelihood support to fish worker community. Apart from the Fisheries Department, Kerala Fisherman’s Welfare Fund Board and Matsyafed also implement such schemes. Plan support is also available for many such schemes. Some of these schemes are Centrally Sponsored Schemes. Schemes include those for Housing, Insurance, and Pension etc apart from those which enable fish workers to earn livelihood on a continuous basis. 2.36 lakh fish workers benefitted from Group Accident Insurance Scheme.

Additionally, 77,597 allied workers also benefitted from Group Accident Insurance Scheme. Old age pension was provided to 55,335 fish workers. Number of beneficiaries under the scheme "Pension for wives of deceased fish workers" was 9,965. Fund was provided for motorisation of 200 fishing crafts and subsidy was provided to 960 fish 
workers for the purchase of fishing gear. 1.9 lakh fish workers were provided support during the 'off season' under the 'Saving cum Relief Scheme'. The State has been able to provide greater assistance to the fish worker community, and expand the social security net over the years.

\section{MATSYAFED}

Matsyafed is an apex federation of 651 primary level Fish workers Development Welfare Co-operative Societies, of which 335 are in marine sector, 198 are in inland sector and 118 women co-operative societies. The total membership in these societies is more than 4.45 lakh. The Authorized share capital of the federation is 150 crore. Matsyafed has organized Self Help Groups within the fishing community and has developed among them, the habit of savings. These groups have mobilized money as thrift. By providing micro finance and interest free loans, Matsyafed has made a significant impact in the area of micro credit. In 2016-17 micro finance support was provided to SHGs which have benefitted 26,400 beneficiaries. 17,928 fisherwomen were provided Interest free loans. Matsyafed has also been successful in enabling the fish workers have access to vital fishing inputs. 899 fish workers have benefitted from the scheme providing subsidy for suitable complements of fishing gear.

\section{A. Society for Assistance to Fisherwomen (SAF) and Women Empowerment}

From last couple of years, Society for Assistance to Fisherwomen (SAF) has a great role in enhancing socio economic condition of fisherwomen of the state. 11 SAF is registered organization under Travancore Cochin literary and charitable societies Act. This organization came into existence for betterment of fisher women in Kerala after the destruction thousands of fishermen community by the tsunami in 2004 in coastal area of Kerala, many of them lost their lives, houses and means of livelihood. 12 there are many initiatives running under this program like Vembanad project and Theeramythri program. These enterprises are aimed the Upliftment of this community and eradication of poverty from fishing folks by collective actions like implementation of various projects to enhance the income generation by improving livelihood and by providing new collective activities, like promoting and developing new micro enterprises, establishments of new common infrastructure facilities like community training centers, common production centers and crafting marketing supports.

It extends financial, technological and managerial support to fisherwomen to organize as group activity, start micro enterprises and run the business in a sustainable manner. In order to promote alternative livelihood activities especially for development of micro enterprises among fisherwomen, assistance was provided to 320 beneficiaries and capacity building training was provided to 542 beneficiaries. In order to ensure sustainability of existing units, working capital revolving fund was provided to 588 units, avenues for technology improvement was provided to 100 units and capacity building training was provided to 1025 units. 336 fisherwomen benefitted from the Theeranaipunya scheme which seeks to equip fisherwomen below the age of 30 for future.

TABLE I DistRICT WiSE NUMBER OF SAF UNITS

\begin{tabular}{|l|c|}
\hline \multicolumn{1}{|c|}{ Name of Districts } & Number of SAF Units \\
\hline Thiruvananthapuram & 140 \\
\hline Kollam & 422 \\
\hline Alappuzha & 303 \\
\hline Ernakulum & 276 \\
\hline Thrissur & 207 \\
\hline Malappuram & 124 \\
\hline Kozhikode & 201 \\
\hline Kannur & 125 \\
\hline Kasaragod & 84 \\
\hline Total & 1882 \\
\hline \multicolumn{2}{|c|}{ Source: Annual Report, 2016 by CMFI, Kochi }
\end{tabular}

The main objective of this SAF is to promote integrated sustainable development by training them to be engaging in other than fishing activities, which help them to secure their economic condition of fishing community. Now this project has been very popular in coastal villages of Kerala, it has a great impact in everyday life of fisher folks than other project like Kudumbashree program.16 Now Theeramythri have around1882 units which are in operation across six different categories viz. garments and textiles, food, coir, fish, supermarket and others along the nine coastal districts of Kerala.

\section{B. Key Initiatives during 2017-18}

Inland fish production is an area which holds promise for future in Kerala. Insufficient availability of good quality fish seeds was identified as a major problem. To increase the production of fish seeds and to ensure quality, it is required to strengthen the existing hatcheries, nurseries, fish farms and construct new units to the existing infrastructure. During 2017-18, an amount of 48.88 crore is allocated for inland fisheries including 28.38 crore specifically for Aquaculture. In order to eliminate the problem of loss of life while fishing at sea, fund was provided for procurement of sea rescue craft.

In order to address the relative backwardness of the fisher folk population and the fishing community, the State of Kerala had initiated a new scheme 'Basic infrastructural facilities and human development of fisher folk' in 2015-16. The outlay to the scheme is 216 crore in 2017-18 of which 150 crore is provided exclusively for rehabilitation of fish workers who stay within 50 mtrs from the coast, and are vulnerable to sea erosion. Provision for purchase of land and construction of house are built into the scheme. 
In the 11th Five-Year Plan, marine fisheries sector achieved growth especially in the area of infrastructure development. The 12th Five-Year Plan strategy was to ensure sustainable growth of Fish and Fisheries for nutrition, food security and economic growth by ensuring proper utilization of infrastructure created in the last Plan. Special emphasis was given to conservation and management of inshore fishery resources, enhancement of offshore marine fish production, maximum utilization of harvested fish and value addition.

As the State enters the 13th Five-Year Plan, Fisheries sector is looked upon with interest due to its immense potential to contribute positively towards development. The sector needs to take upon itself objectives like (a) nutritional security through enhancing fish production and (b) poverty reduction among fisher folk by ensuring distribution of production benefits to the community on a sustainable and equitable basis. These must be achieved keeping in mind the challenges posed by climate change and degradation of environment. The resource base of the State offers ample scope for growth of aquaculture especially in the inland waters. An active role and contribution from LSGIs can bring a revolutionary change in this direction. Resource conservation and elimination of harmful fishing practices need greater emphasis in the future endeavors, since only they can ensure a sustainable catch in the future. With adequate technological support and extension activities, the sector can be expected to do well and be a sunrise sector in the coming years.

Kerala Fishermen's Welfare Fund Board (Matsya board) Safety nets, stands for social security measures and schemes devised to mitigate the possible adverse effects of reform measures on the poor, a kind of social protection provided to the vulnerable sections of the society to support and to include them in the process of development. Generally it is translated in the form of subsidy for the basic life cycle requirements and special schemes for the aged people, facing disability due to accident and other reasons like unemployment, sickness and natural calamities (Chu \& Gupta, 1998). The World Bank defined safety nets as noncontributory measures fashioned to provide regular and predictable support to the vulnerable sections of the society (World Bank, 2015).

Kerala Fishermen's Welfare Fund Board came into existence in 1986 as a formal social security institution to implement the welfare schemes framed for the registered fishermen and women of Kerala realizing the risk they assume in this sector and the socio-economic backwardness they face due to the irregular/seasonal nature of the occupation. Matsyaboard has its headquarters in Thrissur and to coordinate the state level activities, it has five regional offices in five districts in Kerala. As a last link to the target group, it has 54 fisheries offices at lower level. Matsyaboard's safety nets comprised of schemes for fishermen's medical care, life insurance, maternity benefit, promoting education of the fishermen's children, employment injury pension, old age pension and props to meet some of the life-cycle needs and emergency needs of the family. Over the 201 years, Matsyafed has implemented various welfare schemes. John Kurian and Antony to Paul classified them as protective schemes and promotional schemes. These social security schemes were framed after the recommendation of the 102 nd convention of International Labour Organization on Minimum Standard for Social security Security (ILO, 2012). Matsyaboard commenced with just two welfare schemes, but at the time of its silver jubilee, it could implement 26 schemes (Mohankumar, 2011). The major sources of finance for implementing these schemes are contribution from the fishermen, fishing input owners and sea food exporters. (Department of Fisheries, Kerala). Unfortunately, the reluctance shown by the sea food exporters slow down the smooth implementation of the welfare measures for the fishermen. From 1999, Matsyaboard has taken up an added financial burden of extending some of the welfare measures for the allied workers who share the ripple effects of resource depletion and reduction in the fish production together with their counter parts. Table 4.13 presents the coverage of the safety net spread by the Matsyaboard including the newly installed schemes under Aam Admi Bima Yojana (AABY) intended to provide social safety offered for the households falling below the poverty line and other identified household marginalized groups and rural landless households. Under the scheme, a few more measures came into force from 01.01.20

\section{SOURCES OF FINANCE}

Sources of Finance Depends on The schemes implemented by the various promotional agencies for fisher community though commendable, lack adequacy which push them to the money lenders from the time of setting up of a fishing unit itself. Major sources fishermen depend on for finding the balance amount beyond the loan sanctioned by Matsyafed are own source, relatives and friends, money lenders and commission agents. Micro finance institutions are also resorted through other family members like homemaker of the house, mother and neighbours. Number of Microfinance players is mushrooming in the coastal belt day by day, due to the tempting profit and 100 per cent repayment through cohesive method adopted for collecting back the loan. Out of the 13 Micro finance institutions seven of them have taken root in Alappuzha coastal belt (Sa-Dhan, 2014).

SKS Microfinance Ltd (Swayam Krishi Sangam), ESAF Microfinance and Investment Pvt. Ltd now turned ESAF Small Finance Bank, Ujjivan Finance Service Ltd, Dora Microfinance, FREED, Janashree Microfinance Ltd, Muthoot Finance Ltd and Self Help Groups which falls under various NGOs are the prominent ones catering to the fisher holds for years. An earlier study conducted by Matsyafed, revealed that 82.8 per cent of the respondents were depending upon the money lenders for meeting the balance amount beyond the sanctioned loan amount (Matsyafed, 2006). Besides the occupational financial 
needs, fisher households were depending on informal sources. Each and every fisher household has been indebted to more than three informal sources at a 215 time. A few also have taken loans from co-operative societies too. Recent report said that as per the 'Operation Kubera' launched to control the illegal money lending, 3200 cases were registered and 2140 persons were arrested in this regard for illegally holding the documents worth 4.67 crore.

\section{FINANCIAL INCLUSION MODEL FOR FISHER HOUSERHOLDS}

Nachiket Mor committee on 'Comprehensive Financial services for small Scale Business and low income household', January 2014, fixed six time bound target. The committee envisioned adequate formal credit, convenient 217 and suitable financial products and services and the availability of sufficient access points, for secure and full financial services. Universal Electronic Bank Account: Each Indian citizen above the age of 18 years would be entitled to secure full banking service by January 1, 2016. Access Points within 15 minutes walking distance for Payment Services and Deposit Products at Reasonable Charges: Intended to provide easy access to financial services Sufficient access to affordable formal credit to lowincome and small business units by January 1 2016: And set a benchmark to assess the credit growth as Credit to GDP ratio, which should be at least 10 per cent and this rate would be increased by 10 per cent every year which will reach 50 per cent by January 1, 2020.

Universal Access to a Range of Deposit and Investment Products at Reasonable Charges: Convenient access to all by Government regulated institutions. It aims at attaining a goal of Total Deposit and Investment to GDP ratio 15 per cent at District level and this ratio would keep increasing every year by 12.5 per cent to reach 65 per cent within four years. Universal Access to a Range of Insurance and Risk Management Product at Reasonable Charges: To provide convenient access to suitable insurance and risk management by regulated institutions. It targeted to have a Total Term Insurance Sum Assured to GDP ratio of at least 30 per cent at district level and reach to 80 per cent within four years sustaining the growth rate by 12.5 per cent every year. Right to Suitability: To protect the right of lowincome households and small-business houses to avail suitable financial services, with informed consent and legal redressal if needed.

Fisher households with low and seasonal income have unique financial requirements. Availability of adequate institutional credit to the fisher folk has been studied by different agencies like FAO, SIFFS etc. FAO has produced a management guideline in providing revolving loans and credit programmes for fisher communities. It proposed to do a spade work to convince the fisher community about the difference between grants and loans, steps to be taken in case of willful default, loan recovery arrangements and the legal proceedings (FAO, 1986). However, it should remind the service-providers to know the socio-economic background of the fisher borrowers and to have constant follow up after giving financial assistance. FAO study concluded to say that a deep relationship with the borrower and his family would help the banking personnel to comprehend his income, his investment and spending pattern with greater accuracy.

Nachiket Mor Committee envisions adequate formal credit, convenient and suitable financial products and services, availability of sufficient access points for secure and full financial services through the financial inclusion drive. Affordability, adequacy and suitability are the qualitative dimensions of financial inclusion put forward by this committee for meaningful financial inclusion in India. These dimensions should be discussed before formulating a viable model of financial inclusion for the fisher households. A model proposed would place client needs at the centre, reaching to the fisher households in the fisheries villages with the smart integration of the technology and collaboration with multiple institutions offering a wide range of products and services.

Fisher households are well-aware that higher rate of interest is charged by the money lenders and microfinance institutions in comparison to the interest charged by the formal financial institutions. But the terms and conditions of the banks make the fisher households to keep a distance from the formal financial institutions. In order to reduce this distance, adequate loans could be provided taking into account cash flow of the fisheries sector and flexibility in repayment conditions. Fishing industry is capital intensive; huge investment may not be possible by fishermen with less or poor asset possession to offer to banks for raising loans. But the right to avail suitable financial products, which encompasses a broader concept of financial inclusiveness as 'distributional objectives' rather than mere poverty reduction tool (Ahluwalia, 2007).

Principal criterion followed by fishermen in deciding the sources of finance is the availability of adequate sum to meet the need. Most of the time, money lenders provide hassle-free credit to the working capital requirements of fishermen. Overdraft facilities could be provided to the credit worthy clients to meet the emergency like sudden repair of engine and webbings. Suitability was considered in terms of regional language, working hours and location of the service points.

Working hours should be suited to their occupation, as the fishermen reach back to the place of residence from landing centres in Ernakulam and Kollam by 4.00 p.m in the evening. They have to wait for another day to make a visit to the bank. And finally, fisher household in Mararikulam, Azheekal, Thyckal and Pallithode fisheries villages have to travel more than 7-8 kilometers to reach to the bank in Arthunkal, Thanky and Pattanakad bank which is '15 minutes walking distance from the residents' concept of Nachiket more committee (Chauhan, 2014). 


\section{CONCLUSION}

"Inclusiveness" was a concern for India since Independence. It was spelled out in terms of social objectives by the policy makers from the very beginning of the Five Year Plans of India. But still, India was prompted to give thrust for 'faster and more inclusive growth' by ensuring financial access to all especially low-income households and weaker sections of the societies only with the Eleventh Five Year Plan. The policy makers, regulators and the other players need to share the same dreams and plans to achieve this target. It demands a mentality of change regarding the current banking services in order to ensure financial inclusion among low-income group like the fisher households. An approach of supply-driven 'one-size fits for all' should give way for customized and flexible terms and conditions. In the case of fisher households credit should be linked with source of income, knowing the 220 customer personally on his income, needs and risks. It calls for various stakeholders including Governments, promotional agencies and formal financial institutions to save the fisher households from the private money lenders. The effectiveness of financial inclusion efforts of commercial banks for marine fisher households could be assessed in terms of the responsiveness, affordability and suitability of financial products and services commercial banks offer to the marine fisher households.

\section{REFERENCES}

[1] Department of Fisheries (2013). Kerala Marine Fisheries Statistics. Government of Kerala, Thiruvananthapuram.

[2] Department of Fisheries (2010). Theeramaithry. Development of Small Scale Enterprises. Alappuzha. Deputy Directorate of Fisheries, Alappuzha.

[3] Department of Fisheries, Kerala (2008). A study report on the fisher folk and their indebtedness - In connection with Debt Relief Commission Bill Thiruvananthapuram: Kerala State Fisheries Department, Vikas Bhavan.

[4] Department of Fisheries Kerala (2012). Integrated Sea Safety ProjectSafety to Fishermen, Security to Nation and Sustainable Development of Marine Fisheries. Department of Fisheries, Government of Kerala.

[5] Department of Fisheries, Kerala (April 14, 2013). Kerala Fishermen's Welfare Fund Board, (KFWFB), Government of Kerala, Department of Fisheries.

[6] Chauhan, R. (2014). Financial Inclusion-Present Scenario in India with Nachiket Mor Committee Vision. International Journal of Commerce, Business and Management, 3(4), 558-86.

[7] FAO (2010). Safety at Sea for Small-Scale Fisheries in Developing Countries. Retrieved August 13, 2015, Government of Kerala, Department of Fisheries. (2015, July 14).

[8] N. Ram (02 Dec. 2016). Empowering fishermen. The Hindu News Paper. Web. 21 Feb. 2017.

[9] Mathew, George. (9 Jan 2001, Web.20 Feb 2017), Amartya Sen \& the Kerala 'model. The Hindu News Paper.

[10] Pillai, R. Ramabhadran. (6 July 2015). Reaching out to fisherwomen. The Hindu News Paper, Web. 21 Feb. 2017. 